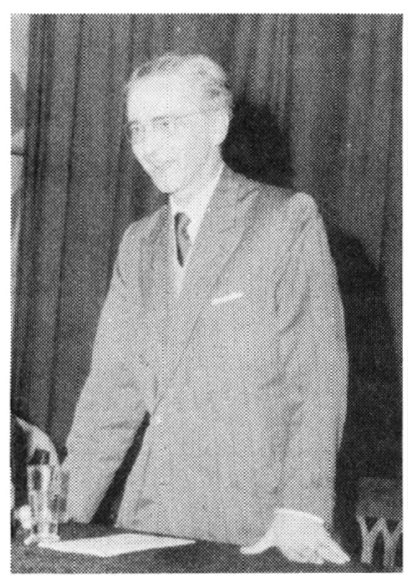

\title{
Lourenco Filho
}

Manoel Bergström Lourenço Filho nasceu no dia 10 de março de 1897 . em Porto Ferreira (SP) e faleceu no Rio de Janeiro, em 3 de agosto de 1970 , aos 73 anos.

Realizou estudos primários em Porto Ferreira e em Santa Rita de Passa Quatro. Em 1910, matriculou-se no Ginásio de Campinas, curso que interrompeu para se inscrever na Escola Normal Primária de Pirassununga (1912). Concluído o curso da Escola Normal (1914), exerceu o magistério primário em sua cidade natal. (1915). No ano seguinte, transferiu-se para a capital paulista, onde estudou na Escola Normal Secundária (Praça da República) e obteve novo diploma de professor. Com a intençāo de se dedicar à psiquiatria, ingressou na Faculdade de Medicina de São Paulo (1918); no final do segundo ano, desistiu do curso de medicina. Em 1929, recebeu o grau de bacharel em Ciências Jurídicas e Sociais, pela Faculdade de Direito de São Paulo.

A partir de 1920 iniciou, propriamente, sua vida profissional, até a morte, a serviço da psicologia e da educação. Lecionou educação cívica e pedagogia na Escola Normal Primária de São Paulo (1920); psicologia e pedagogia, na Escola Normal de Piracicaba (1921); psicologia educacional na USP (1934) e na Universidade do Distrito Federal (1935), posteriormente Universidade do Brasil (1937).

Sempre motivado para responder a novos desafios, entre outras atividades, organizou o ensino público do Ceará, onde criou um laboratório de psicologia (1920); organizou a Biblioteca de Educação, Editora Melhoramentos (a partir de 1926), reorganizou o ensino normal e o ensino profissional de São Paulo e criou o Serviço de Psicologia Aplicada de São Paulo (1931); integrado no movimento escolanovista, escreveu um livro básico para se compreender o movimento (Introducáo ao Estudo da Escola Nova, 1930) e foi um dos signatários do Manifesto dos
Pioneiros; organizou e dirigiu o Instituto Nacional de Estudos Pedagógicos (1938-1946); fundou a Revista Brasileira de Estudos Pedagógicos (1944); Estimulador da vinda do Professor Mira y López para o Brasil e da criação do ISOP (Instituto de Seleção e Orientação Profissional), dirigiu durante vários anos os Arquivos Brasileiros de Psicotécnica (Mira y López, como diretor do ISOP, era seu redator chefe); participou, ativamente, das discussōes para a elaboraçāo da LDB e para a regulamentação da profissão de psicólogo. Escreveu livros e artigos de referência obrigatória nos campos da psicologia e da educaçāo: Testes ABC (1933); La penseé de Ribot dans la psychologie sud-américaine (1939); Psicologia educacional (1955/56); Tendências da educação brasileira (1940); A psicologia a servico da educação (1943); A Psicologia no Brasil (1955); A orientacão profissional e as carreiras liberais (1963); a Psicologia no Brasil nos últimos 25 anos (1969). Para as crianças, preparou as histórias do Tio Damiāo. Traduziu, para o português, obras de E. Durkhein (Educação e Sociologia), de Binet e Simon ( Testes para a medida da inteligência) e de Léon Walther (Tecno-psicologia do trabalho industrian.

Boring (A History of Experimental Psychology) escreve sobre o dinamismo e a influência de G. Stanley Hall na formação da psicologia nos Estados Unidos da América: Stanley Hall, confirmam historiadores da psicologia, foi o "promotor" da psicologia norte-americana. De Lourenço Filho cabe, igualmente, reconhecer seu dinamismo e influência na formação da psicologia no Brasil, seu papel histórico como um dos "promotores" da psicologia brasileira.

\section{Fontes Principais:}

Ruy Lourenço Filho: Cronologia e Bibllografia do Professor Lourenço Filho (ABE, 1996)

Revista Brasileira de Estudos Pedagógicos: v.54, nº119, Jul-set de 1970

Revista Brasileira de Estudos Pedagógicos: v.65. n¹50, mai-ago de 1984

Revista Brasileira de Estudos Pedagógicos: v.23, n³, julset de 1971

Lourenço Filho: outros aspectos, mesma obra. Carlos Monarcha(ord). Mercado de Letras, Campinas, 1997 